\title{
Experimental Model for Biological Control of Stored
}

\section{Grain Pests}

\author{
Manole Traian ${ }^{1}$, Lupu Carmen ${ }^{1}$, Fătu Viorel ${ }^{1}$, Chiriloaie Andrei ${ }^{1}$ and Chițoran Florentin ${ }^{2}$ \\ 1. Research-Development Institute for Plant Protection, Bucharest 013813, Romania \\ 2. S.C. Agrotehnic Păulești, 107400, Prahova District, Romania
}

\begin{abstract}
The insecticidal efficacy of the diatomaceous earth against granary weevil, Sitophilus granarius L. (Coleoptera: Curculionidae), with two essential oils for the degree of repellent activity, was evaluated in an experimental model in laboratory tests. The diatomaceous earth was obtained from three Romanian sources (Pătîrlagele, Urloaia and Adamclisi) and was applied at four doses of 100, 300, 500 and $900 \mathrm{ppm}(5,15,25$ and $45 \mathrm{mg}$, respectively) on three replicates each variant. Mortality of $S$. granarius adults was estimated after 7, 14 and $21 \mathrm{~d}$ of exposure on treated grain. The insecticidal efficacy of the examined diatomaceous earth against the granary weevil was highly influenced by exposure time, dose and essential oil type. The longer exposure times increased weevil mortality in the case of low doses $(100 \mathrm{ppm}$ and $300 \mathrm{ppm})$. After $60 \mathrm{~d}$ from the experiment initiation, the exposed grains from each variant were assessed about the progeny production. For the model proposed as bio-experiment, two essential oils in concentration of $80 \mu \mathrm{L} / \mathrm{L}$ air and $125 \mu \mathrm{L} / \mathrm{L}$ of Thymus vulgaris L. and Satureja hortensis L., respectively, were tested compared with untreated control in laboratory conditions. Both plant species belong to the family Lamiaceae, and the major active insecticidal compound was thymol among other providing to terpenoid class, such as eugenol and linalool. The species $S$. granarius chosen for experimental model was grown in the Research-Development Institute of Plant Protection (RDIPP) Bucharest bio-base. The results show that mortality induced from diatomaceous earth was at the level between $83.33 \%$ and $100 \%$ in all variants after $21 \mathrm{~d}$, compared with untreated control and a standard product Silicosec ${ }^{\circledR}$.
\end{abstract}

Key words: Diatomaceous earth, integrated experimental model, essential oils, S. granarius.

\section{Introduction}

The increasing grain production exceeds the direct consumption or export capacities and imposes the yield storage in properly conditions, so that the grains are suitable for consumption in terms of ensuring food safety. Methods intended to ensure these conditions should not be polluting for the environment. Besides these problems which resulted primarily from the need to use alternative methods, insect resistance is the major problem of harmful chemical pesticides action. Stored-product insects can cause postharvest losses, estimated from up to $9 \%$ in developed countries to $20 \%$ or more in developing countries [1]. In response to feeding by arthropods, plants actively and systemically emit various organic volatile compounds

Corresponding author: Manole Traian, Ph.D., research field: entomology.
(VOCs). It has been proposed that these herbivore-induced volatiles can be exploited in agricultural pest control, because they might repel herbivores and they serve as attractants for the natural enemies of herbivores. Plant defenses against herbivores are not limited to physical and chemical barriers that directly aim to harm their attackers; it is becoming increasingly evident that plants also employ strategies of indirect defense [2]. On the stored grain, both effects of the VOCs are interesting, even that the VOCs emissions are not so strong, like those of the living plant; in the case of the repellent or attractant effect of some VOCs emissions, the effect can be stimulated and enhanced by active botanical VOCs added. Some essential oils could have strong repellent effect on S. granarius adult population and that was the motif that the diatomaceous earth is applied on the opposite side of the stored grain towards the essential 
oil. In case of attractive effect of the oil bait, the diatomaceous earth could be applied together for enhancing the killing effect on S. granarius. Beside of the VOCs, insect interactions were already expressed in repellence or like insecticidal effect [3-7]. Many other researches had studied the effect of some botanical VOCs on the development and behaviour of some important natural enemies of some pest in order to enhance the level of natural biological control [8-11]. The use of two integrated method of stored grain pest control combined by insecticidal effect of diatomaceous earth and manipulation with VOCs emissions was the original new solution to have been applied into the experimental model of stored grain pests.

The granary weevil Sitophilus granarius L. is a typical cosmopolitan pest. It can cause significant damage to stored grains, and may drastically decrease yields $[12,13]$. A female lays an average of 125 eggs [14], and the larvae and the adult eat the inside of grain kernels [15]. Damaged grain has reduced nutritional value, low percentage germination, reduced weight and lowered market value. Environmentally safe, cheap and effective methods for reducing $S$. granarius damage are needed to protect stored grains $[16,17]$.

The objective of this research was to evaluate the efficacy of some diatomaceous earth samples in insect control technique in one experimental model of integrated pest management program on stored grain.

\section{Materials and Methods}

\subsection{Model Components}

The experimental model tested consists in integrating of two alternative methods of stored grain pest control: insecticide effect of diatomaceous earth and repellent or attractive effect of some essential oils baits. The first component of the model consists of a biological action of diatomaceous earth mineral, where the symptoms occurs by rapid dehydration of pest insect tissues, causing finally the death by water losses. The insecticidal action of diatomaceous earth varies depending on the mineral composition, geological or geographical origin, as well as of the specific chemical characteristics, such as the $\mathrm{SiO}_{2}$ content, $\mathrm{pH}$ and particles size. The samples of diatomaceous earth were obtained from the owners of Romanian mines and were finely grinded into powdered silica with particles size of 13-15 $\mu \mathrm{m}$. The diatomaceous earth formulations do not contain any synthetic additives. Preliminary tests were performed on both integrated components of the model; the preliminary testing of diatomaceous earth biological action was by directed skin contact, ingestion or "no action".

As comparative control used in the proposed experimental model, beside untreated control plot, the product SilicoSec ${ }^{\circledR}$ (Biofa AG, Münsingen, Germany) is a natural alternative for controlling pest populations in stored grains, which is active against all types of insects or different mite's species.

The second component of the model consists in essential oils, i.e., Thymus vulgaris L. and Satureja hortensis L., and their complex mixture of volatile organic substances [18]. The integration of these two components in the model was done by working protocol in simulating the real conditions from storehouse natural ambient (temperature, humidity, light, heat, aeration and so on).

\subsection{Insect Rearing}

The insect test population was the adults of $S$. granarius which are reared in the institut facility in special rooms with the physical parameter digitally conditioned (temperature of $25 \pm 2{ }^{\circ} \mathrm{C}$, relative humidity of $70 \% \pm 5 \%$ and of $8 / 16 \mathrm{~h} \mathrm{light/ \text {dark }}$ photophase).

\subsection{Bioassays}

Untreated, clean wheat kernels free from infestation by bacteria, fungi or pests were used for experimentation. The experimental design was 
comprised of five test variants, which consist of three diatomaceous earth (Pătîrlagele, Urloaia and Adamclisi), applied at four doses, 100, 300, 500 and $900 \mathrm{ppm}$, respectively, and compared with untreated control and standard SilicoSec ${ }^{\circledR}$. The grain samples for each dose were placed in small plastic vials and the weight of grain was $50 \mathrm{~g}$. The added essential oil was at $0.05 \%-2 \%$ concentration. And the uniform distribution of both compounds in the grain was secured by $5 \mathrm{~min}$ of thorough mixing. The essential oils repellency was previously evaluated at 0.6-10.4 $\mathrm{mg} / \mathrm{cm}^{2}$, whereas the oil activity was tested both in air and admixture with grain, at $80 \mu \mathrm{L} / \mathrm{L}$ air and 125 $\mu \mathrm{L} / \mathrm{L}$. In the plastic vials, 30 healthy $S$. granarius adults of mixed sex were added, after the vials were covered with well-ventilated textiles and placed in laboratory at $25 \pm 2{ }^{\circ} \mathrm{C}$ and $60 \%$ relative humidity. Dead adults were counted after 7, 14 and $21 \mathrm{~d}$. After the 21 st day count, all adult insects (dead and alive) were removed from the vials, and then the vials were returned to the laboratory in the same conditions for another $39 \mathrm{~d}$ (Table 1). After this period, the emerged S. granarius adults were counted, classified as dead or alive and removed from the vials. Mortality counts were corrected by using Abbott's (1925) formula [19]. The data were analyzed by using one-way ANOVA of SPSS 11.5 software, with weevil mortality as the response variable and exposure time and dose rate as the main effects. Insect mortality was compared with students' $t$-values, using Microsoft Office Excel 2007.

\section{Results}

Active oil has been tested to establish the degree of repellent activity against grain weevils, and better repellent activity was shown by thymol-based essential oil. The results of this study indicated that essential oil of Thymus vulgaris L. may be considered as a bio-pesticide to control $S$. granarius in stored grain. The volatile oils test was carried out to indicate the degree of repellent activity against $S$. granarius populations. The results shown in Fig. 1 indicate that at the concentration of $125 \mu \mathrm{L} / \mathrm{L}$, the essential oil obtained from Thymus vulgaris had a significant repellent effect compared with untreated control.

Romanian samples of diatomaceous earth had satisfactory results starting with $300 \mathrm{ppm}$ level. The insect mortality after $21 \mathrm{~d}$ of the wheat grain treatment is shown in Table 2. High values of $S$. granarius mortality (percent of individuals) appeared at the lowest dose in all variants. No significant differences were observed between the applied doses on the first two periods of observations compared with untreated control, but the best results seem to be in variant $\mathrm{V}_{1}$, of which the high value of mortality was high from

Table 1 The essential oils effect tested in the laboratory bioassay against $S$. granarius adults.

\begin{tabular}{lll}
\hline Essential oils concentration & \multicolumn{2}{c}{ Behaviour effect on $S$. granarius adults } \\
\cline { 2 - 3 } & Repellent effect & Attractive effect \\
\hline T. vulgaris $80 \mu \mathrm{L} / \mathrm{L}$ & $48 \pm 2$ & $2 \pm 1$ \\
S. hortensis $125 \mu \mathrm{L} / \mathrm{L}$ & $5 \pm 1$ & $35 \pm 4$ \\
Untreated control (clean air) & & $49 \pm 1$ \\
\hline
\end{tabular}

Repellent and attractive effects are all mean of three replicates.

Table 2 The efficacy of diatomaceous earth against species S. granarius L. in laboratory conditions.

\begin{tabular}{lllll}
\hline \multirow{2}{*}{ Variants } & \multicolumn{3}{c}{ \% of mortality after $21 \mathrm{~d}$} \\
\cline { 2 - 5 } & Dose $=100 \mathrm{ppm}$ & Dose $=300 \mathrm{ppm}$ & Dose $=500 \mathrm{ppm}$ & Dose $=900 \mathrm{ppm}$ \\
\hline $\mathrm{V}_{1}$ (Pătîrlagele) & 86.66 & 98.22 & 100.00 & 100.00 \\
$\mathrm{~V}_{2}$ (Urloaia) & 80.12 & 86.66 & 90.44 & 96.66 \\
$\mathrm{~V}_{3}$ (Adamclisi) & 75.55 & 88.66 & 91.88 & 95.70 \\
$\mathrm{~V}_{4}$ (Silicosec & $\left.{ }^{\circledR}\right)$ & 100.00 & 100.00 & 100.00 \\
$\mathrm{~V}_{5}$ (untreated control) & 100.00 & 0.00 & 0.00 & 6.66 \\
\hline
\end{tabular}


the lowest dose $(86.66 \%$ at $100 \mathrm{ppm})$ and of course in variant $\mathrm{V}_{4}$ treated with Silicosec ${ }^{\circledR}(100 \%)$.

\section{Discussion}

Biological control may be a very effective pest management strategy, and among these, essential oils and diatomaceous earth should be a low cost and eco-friendly alternative, safe for stored grain, effective against pests and/or pathogenic fungi. Preliminary studies were carried out in Romania for the first time with good results using an experimental model against the granary weevil $S$. granarius [20, 21]. The developed experimental model includes two integrated components that can be used both independently and simultaneously to potentiate their biological action against stored grain pests. All main effects were significant for all exposure intervals, except for $\mathrm{V}_{2}$ and $\mathrm{V}_{3}$ variants. The results are in accordance with previous laboratory tests, which indicated that SilicoSec ${ }^{\circledR}$ is effective against adults of other species of Sitophilus (S. oryzae) [20].

Fig. 1 has shown the relevant chemical interaction of thymol compound, of which repellent effect had induced a behavior of insect motility, stimulating feeding search interruption and removal of the emission source by leaving the chamber with food to those that not contain food-grains of wheat. The movement of the individuals took place within $72 \mathrm{~h}$ after introduction into the experimental vessels. In the meantime, the essential oil included into stored grain was one of the factors to increase the insecticidal effect of diatomaceous earth.

The above discussed efficacy similarities of the different variants of stored wheat grain were confirmed by the results of the statistical analysis, too. Mortality of $S$. granarius was clearly correlated with the doses of diatomaceous earth, but the correlation was more pronounced in the case of the source from Pătîrlagele (Prahova district), then those from Constanța district. The significant mortality difference $(P=0.012)$ caused by the quality of diatomaceous earth increasing has only occurred by the probity analysis (Fig. 2). With increasing diatomaceous earth doses, the adult progeny decreased in all variants from all sources in stored wheat grains (Table 3). At all doses examined, progeny production was higher at the level of 100 ppm, compared with untreated control. Furthermore, a higher proportion of adult progeny died in all variants after increased dose level. After $60 \mathrm{~d}$, total adult progeny production was only about $16 \%$ of the initial weevil population at the $100 \mathrm{ppm}$ dose, but $0 \%$ with the increased dose level. In addition, a complete suppression of progeny production was achieved with the highest dose in stored wheat grain rate.

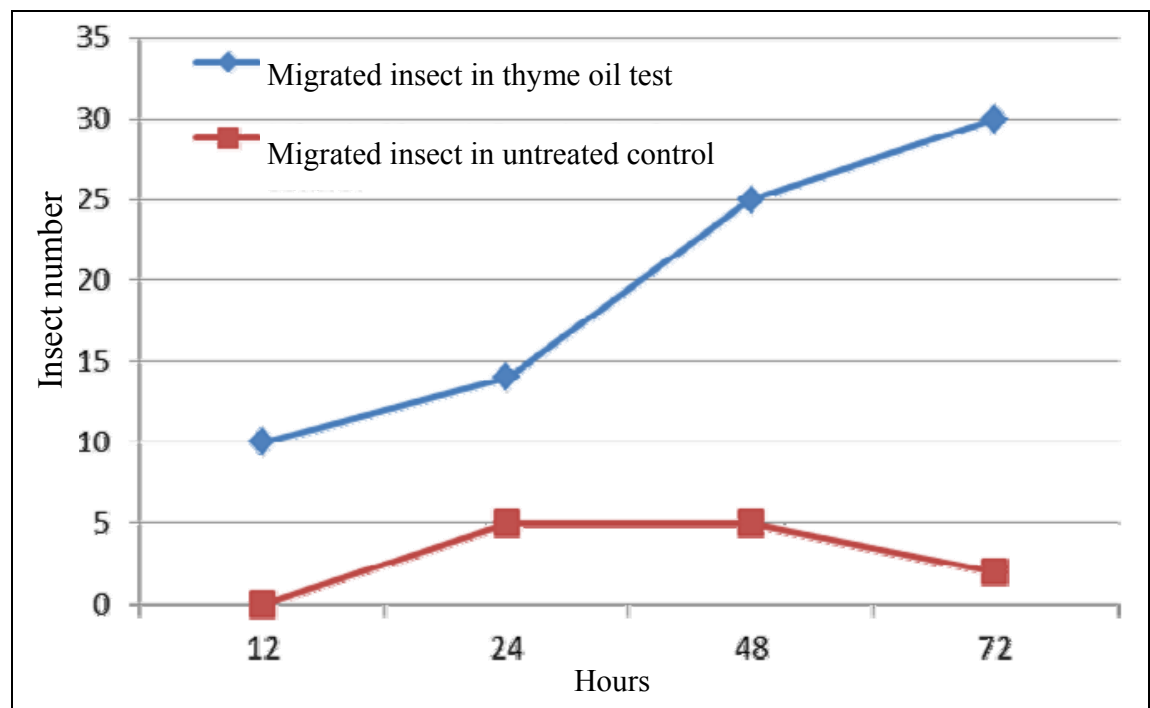

Fig. 1 Thyme essential oil effect (1-80 $\mu \mathrm{L} / \mathrm{L})$ against individuals of $S$. granarius $\mathrm{L}$. in laboratory conditions. 


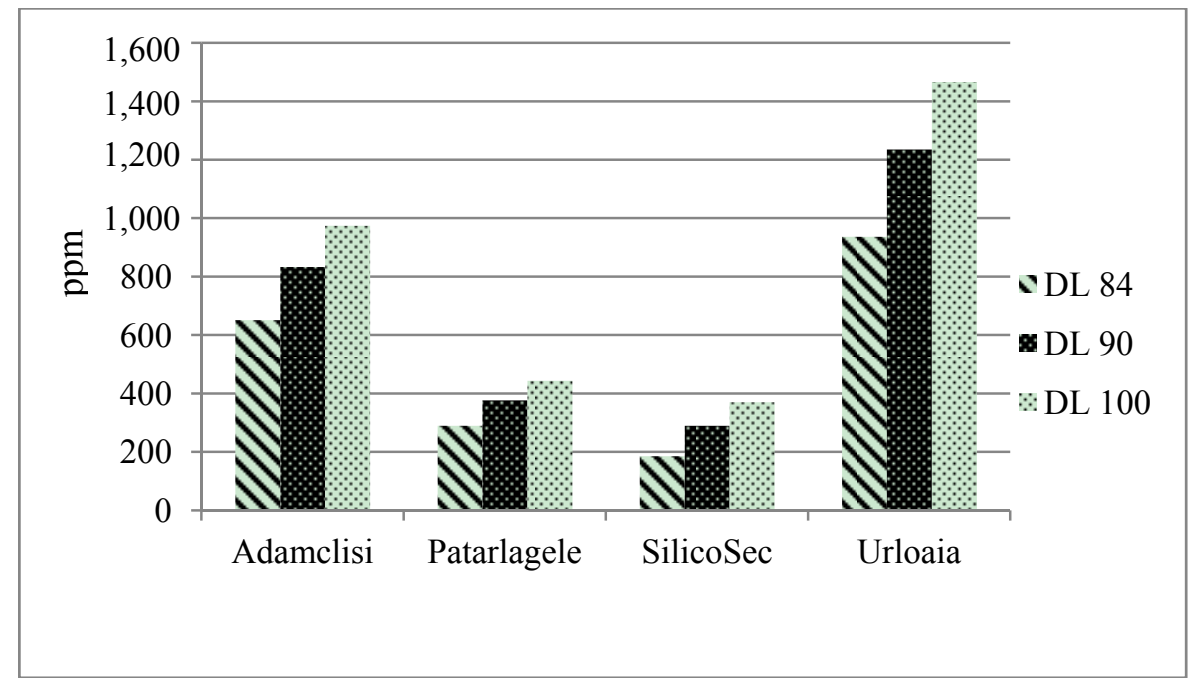

Fig. 2 Calculated mortality (DL 50-100) of $S$. granarius treated with four different dose rates of diatomaceous earth in stored wheat grain.

Table 3 Progeny production of S. granarius and percentage of dead progeny on wheat grain $60 \mathrm{~d}$ after the treatment.

\begin{tabular}{lll}
\hline Diatomaceous earth dose & $\begin{array}{l}\text { Number of progeny } \\
(\text { mean } \pm \text { SE) }\end{array}$ & $\begin{array}{l}\text { \% of dead progeny } \\
(\text { mean } \pm \text { SE) }\end{array}$ \\
\hline $100 \mathrm{ppm}$ & $5.00 \pm 0.10$ & $16.60 \pm 2.23$ \\
$300 \mathrm{ppm}$ & $1.00 \pm 0.56$ & 0.00 \\
$500 \mathrm{ppm}$ & $0.00 \pm 0.11$ & 0.00 \\
$900 \mathrm{ppm}$ & $0.00 \pm 0.12$ & 0.00 \\
Untreated control & $5.33 \pm 2.50$ & $5.44 \pm 4.51$ \\
Standard SilicoSec & $0.00 \pm 0.22$ & 0.00 \\
\hline
\end{tabular}

\section{Conclusions}

The utilization of diatomaceous earth for control of the beetles has several advantages compared to chemical insecticides, such as higher efficacy (especially at the $900 \mathrm{ppm}$ dose), no negative environment effects, no adverse effects to humans or animals and no adverse effects on milling or baking quality of wheat. The results show that mortality induced from diatomaceous earth tested was at the level between $75.55 \%$ and $100 \%$ in all variants after $21 \mathrm{~d}$, compared with untreated control and a standard product SilicoSec ${ }^{\circledR}$. The number of progeny production of $S$. granarius on wheat grain at $60 \mathrm{~d}$ after the treatment was totally reduced at the doses 300-900 ppm in all variants. Semiochemical composition of some essential oils combined into an integrated alternative model of ecological methods can be considered as efficient way of stored grain pest control of $S$. granarius and this could be industrially formulated into a biological compound.

\section{Acknowledgments}

The study was founded by UEFISCDI, PCCA 2013, Contract No. 156/2014 "ecological products based on diatomaceous earth and essential oils for the residues and contaminants reduction from the food chain-PEDIOL".

\section{References}

[1] Phillips, T. W., and Throne, J. E. 2010. "Bio-rational Approaches to Managing Stored Product." Annual Review of Entomology 55: 375-97.

[2] Turlings, C. J., and Ton, J. 2006. "Exploiting Scents of Distress: The Prospect of Manipulating Herbivore-Induced Plant Odours to Enhance the Control of Agricultural Pests." Current Opinion in Plant Biology 9 (4): 421-7.

[3] Khani, A., and Asghari, J. 2012. "Insecticide Activity of Essential Oils of Mentha longifolia, Pulicaria gnaphalodes and Achillea wilhelmsii against Two Stored Product Pests, the Flour Beetle-Tribolium castaneum and the Cowpea Weevil-Callosobruchus maculates." 
Journal of Insect Science 12: 73.

[4] Doumbia, M., Yoboue, K., Kra, D. K., Kimaszewski, J., Kwadjo, K. E., Douan, B. G., and Dagnogo, M. 2014. "Testing of Insecticidal Extract from Mitracarpus scaber Zucc. (Rubiales: Rubiaceae) against Four Stored Food Products Insect Pests in Ivory Coast." Int. J. Entomol. Res. 2: 81-6.

[5] Prinsloo, G., Ninkovic, V., Van der Linde, T. C., Van der Westhuizen, A. J., Pettersson, J., and Glinwood, R. 2007. "Test of Semiochemicals and a Resistant Wheat Variety for Russian Wheat Aphid Management in South Africa." J. Appl. Entomol. 131 (9-10): 637-44.

[6] Martinez, D. S. T., Freire, M. G. M., Mazzafera, P., Araujo-Junior, R. T., Bueno, R. D., and Macedo, M. L. R. 2011. "Insecticidal Effect of Labramin, a Lectin-Like Protein Isolated from Seeds of the Beach Apricot Tree, Labramia bojeri, on the Mediterranean Flour Moth, Ephestia kuehniella." Journal of Insect Science 12: 62.

[7] Lv, C. J., Zhong, B. Z., Zhong, G. H., Weng, Q. F., Chen, S. H., Hu, M. Y., Sun, X. D., and Qin, W. Q. 2010. "Four Botanical Extracts Are Toxic to the Hispine Beetle, Brontispa longissima, in Laboratory and Semi-field Trials." Journal of Insect Science 12: 58.

[8] Doumbia, M., Yoboue, K., Kouamé, L. K., Coffi, K., Kra, D. K., Kwadjo, K. E., Douan, B. G., and Dagnogo, M. 2014. "Toxicity of Cymbopogon nardus (Poales: Poaceae) against Four Stored Food Products Insect Pests." IJFAS Journal 8 (3): 903-9.

[9] Fagundes, M., Neves, F. S., and Fernandes, G. W. 2005. "Direct and Indirect Interactions Involving Ants, Insect Herbivores, Parasitoids and the Host Plant Baccharis dracunculifolia (Asteraceae)." Ecological Entomology 30 (1): 28-35.

[10] Heuskin, S., Lorge, S., Godin, B., Leroy, P., Frère, I., Verheggen, F. J., Haubruge, E., Wathelet, J. P., Mestdagh, M., Hance, T., and Lognay, G. 2012. "Optimisation of a Semiochemical Slow-Release Alginate Formulation Attractive towards Aphidius ervi Haliday Parasitoids." Pest Manag. Sci. 68 (1): 127-36.

[11] Tunca, H., Kilinçer, N., and Ozkan, C. 2012. "Side-Effects of Some Botanical Insecticides and Extracts on the Parasitoid Venturia canescens (Grav.) (Hymenoptera: Ichneuminidae)." Türk. Entomol. Derg. 36 (2): 205-14.

[12] Fava, A., and Burlando, B. 1995. "Influence of Female Age and Grain Availability on the Ovipositional Pattern of the Wheat Weevil Sitophilus granarius (Coleoptera:
Curculionidae).” Eur. J. Entomol. 92: 421-5.

[13] Jávor, I. 1990. "Granary Weevil (Sitophilus granarius L.).” In Handbook of Practical Plant Protection, 1st ed., edited by Jermy, T., and Balázs, K. Budapest, Hungary: Academic Press, 486-91.

[14] Stejskal, V., and Kucerova, Z. 1996. "The Effect of Grain Size on the Biology of Sitophilus granarius L. (Col., Curculionidae): Part 1, Oviposition, Distribution of Eggs and Adult Emergence." J. Appl. Entomol. 120: 143-6.

[15] Keszthelyi, S., and Pál-Fám, F. 2012. "The Effect of the Diatomaceous Earth Formulation DiatoSec on Mortality of Granary Weevil Sitophilus granarius (Coleoptera: Curculionidae) in Grains." Journal of Plant Diseases and Protection 119 (1): 30-3.

[16] Athanassiou, C. G., Kavallieratos, N. G., Tsaganou, F. C., Vayias, B. J., Dimizas, C. B., and Buchelos, C. T. 2003. "Effect of Grain Type on the Insecticidal Efficacy of SilicoSec against Sitophilus oryzae (L.) (Coleoptera: Curculionidae)." Crop Prot. 22 (10): 1141-7.

[17] Athanassiou, C. G., Vayias, B. J., Dimizas, C. B., Kavallieratos, N. G., Papagregoriou, A. S., and Buchelos, C. T. 2005. "Insecticidal Efficacy of Diatomaceous Earth against Sitophilus oryzae (L.) (Coleoptera: Curculionidae) and Tribolium confusum Du Val (Coleoptera: Tenebrionidae) on Stored Wheat: Influence of Dose Rate, Temperature and Exposure Interval." J. Stored Prod. Res. 41: 47-55.

[18] Manole, T., and Fătu, V. 2015, "Behaviour of the Insect Species Sitophilus granarius L. (Coleoptera: Curculionidae) in the Presence of Volatile Thyme Oil." Romanian Journal for Plant Protection 8: 54-7.

[19] Lupu, C., Manole, T., and Chiriloaie, A. 2015. "Effectiveness of Main Sources of Diatomaceous Earth from Romania on Populations of Sitophilus granarius L. (Coleoptera: Curculionidae) under Controlled Conditions." Romanian Journal for Plant Protection 8: 58-62.

[20] Athanassiou, C. G., Kavallieratos, N. G., Vayias, B. J., Tomanović, Z., Petrović, A., Rozman, V., Adler, C., Korunic, Z., and Milovanović, D. 2011. "Laboratory Evaluation of Diatomaceous Earth Deposits Mined from Several Locations in Central and Southeastern Europe as Potential Protectants against Coleopteran Grain Pests." Crop Protection 30 (3): 329-39.

[21] Abbott, W. S. 1925. "A Method of Computing the Effectiveness of an Insecticide.” J. Econ. Entomol. 18 (2): 265-7. 